This article was downloaded by: [University for Miljoe \& Biovitenskap]

On: 1 September 2008

Access details: Access Details: [subscription number 790777004]

Publisher Routledge

Informa Ltd Registered in England and Wales Registered Number: 1072954 Registered office: Mortimer House, 37-41 Mortimer Street, London W1T 3JH, UK

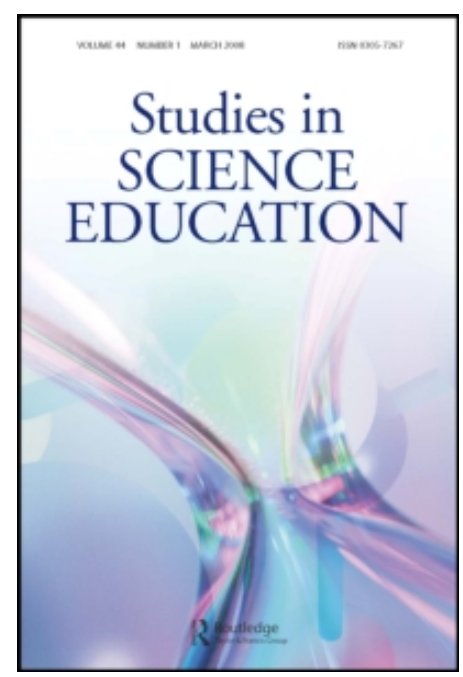

\title{
Studies in Science Education
}

Publication details, including instructions for authors and subscription information:

http://www.informaworld.com/smpp/title content=t790627368

\section{Doing phenomenology in science education: a research review}

Edvin Østergaard a; Bo Dahlin ${ }^{\text {b; }}$ Aksel Hugo ${ }^{\mathrm{a}}$

${ }^{a}$ Institute of Mathematics, Science and Technology, Norwegian University of Life Sciences, Norway ${ }^{b}$ Faculty

of Arts and Education, Karlstad University, Sweden

Online Publication Date: 01 September 2008

To cite this Article Østergaard, Edvin, Dahlin, Bo and Hugo, Aksel(2008)'Doing phenomenology in science education: a research review',Studies in Science Education,44:2,93 - 121

To link to this Article: DOI: $10.1080 / 03057260802264081$

URL: http://dx.doi.org/10.1080/03057260802264081

\section{PLEASE SCROLL DOWN FOR ARTICLE}

Full terms and conditions of use: http://www.informaworld.com/terms-and-conditions-of-access.pdf

This article may be used for research, teaching and private study purposes. Any substantial or systematic reproduction, re-distribution, re-selling, loan or sub-licensing, systematic supply or distribution in any form to anyone is expressly forbidden.

The publisher does not give any warranty express or implied or make any representation that the contents will be complete or accurate or up to date. The accuracy of any instructions, formulae and drug doses should be independently verified with primary sources. The publisher shall not be liable for any loss, actions, claims, proceedings, demand or costs or damages whatsoever or howsoever caused arising directly or indirectly in connection with or arising out of the use of this material. 


\title{
Doing phenomenology in science education: a research review
}

\author{
Edvin Østergaard*a ${ }^{*}$ Bo Dahlin ${ }^{\mathrm{b}}$ and Aksel Hugo ${ }^{\mathrm{a}}$ \\ ${ }^{a}$ Institute of Mathematics, Science and Technology, Norwegian University of Life Sciences, Norway; \\ ${ }^{b}$ Faculty of Arts and Education, Karlstad University, Sweden
}

(Received 7 September 2006; final version received 27 September 2007)

\begin{abstract}
This article is a review of applications of phenomenology, as a philosophy of knowledge and qualitative research approach, to the field of science education (SE). The purpose is to give an overview of work that has been done as well as to assess it and discuss its possibilities of future development. We ask: what attempts for connecting phenomenology and SE do we find in the research literature, and what possible effects could such connections have for teaching and learning? In approaching this field we distinguish between three sources of phenomenological SE: (1) Goethe's phenomenology of nature; (2) philosophical phenomenology; and (3) anthropological phenomenology. Existing research based on phenomenological approaches is categorised as phenomenology of SE, phenomenology in SE, and phenomenology and SE integrated. Research examples from each category are critically evaluated and discussed. Finally we discuss the question of the relevance of phenomenology to science teaching. Our review indicates that phenomenology has considerable potential as a method for investigating science learning as a holistic process. It also seems that phenomenology and SE meet most fruitfully when phenomenology is done in the classroom, that is, when it is turned into actual efforts for promoting learning.
\end{abstract}

Keywords: phenomenology; science education; Goethean science; ontology; reductionism

\section{Introduction}

In the 1975 lecture Save the Phenomena!, Martin Wagenschein sums up his 50 years of experience as a science educator. The lecture explicitly addresses teachers and especially teachers of physics ...

... since I knew that many school children have to suffer lessons in physics that scarcely let them recognise this as the science of nature. Instead, the phenomena of nature are hardly touched upon as the teacher hurries on and goes further into the instrumental, the abstract, the laboratorial, the technical and the mathematical, so that the children no longer can participate with their eyes, ears and hands. Paralysed in a condition as mere spectators they cannot be physically present with their senses, and for this reason they are also unable to perform the task of abstraction (Wagenschein, 1983, pp. 108-109; our translation; italics in original).

This statement can be regarded as the core of the phenomenological critique of current science education. Wagenschein points to the problem that many students in science lessons find themselves faced with an abstract and purely cognitive world, separated from their everyday life experiences. His whole professional life was dedicated to the questions of how to bridge this gap. The numerous examples he gives in all fields of elementary physics of

*Corresponding author. Email: edvin.ostergaard@umb.no 
how rich conceptual understanding can grow step by step out of sense experience illustrate the role phenomenology might play in designing a meaningful science education.

This article presents a review of applications of phenomenology, as a philosophy of knowledge and qualitative research approach, to the field of science education. The purpose is to give an overview of work that has been done as well as to assess it and discuss its possibilities for future development. We enter the field through three general aspects of any classroom situation: the teacher, the student(s) and the subject taught. These three aspects are interconnected, forming a triadic whole and are often considered to be a starting point for theories of curriculum and instruction, especially in the German Didaktik-tradition (cf Hopmann, 2007). From the point of view of each aspect we ask: what attempts to connect phenomenology and science education do we find in the research literature and what possible effects could such connections have for teaching and learning? Since the three aspects are parts of one whole, a fourth point of entrance to the field will be through an overall integration of those three aspects.

We approach this complex field of research stepwise. First, we will introduce the field of inquiry by distinguishing between three sources for phenomenological science education: (1) Goethe's phenomenology of nature; (2) philosophical phenomenology and (3) anthropological phenomenology. Second, we review existing research under the heading of phenomenological approaches to research in science education. Third, we will evaluate critically and discuss the reviewed studies as a basis for exploring the research agenda further, and finally, we will return to the basic question of the relevance of phenomenology to science teaching.

\section{Sources of a phenomenology of science education}

There is a growing interest in phenomenology in current research agendas. As Frykman and Gilje (2003, p. 15) note, phenomenology seems to have an 'attractive force' in several research areas and methodological approaches. One example of this is the rather recent (2002) appearance of a journal called Phenomenology and the Cognitive Sciences.

Historically, phenomenology as a concept or a research practice has existed for about two centuries. Hegel's Phänomenologie des Geistes, which appeared 1807, is perhaps the first well-known use of the term, even though Edmund Husserl is generally considered to be the inaugurator of phenomenology as a modern philosophy and research methodology (see for instance Husserl, 1931). Husserl's ideas were taken up by many thinkers, of whom Martin Heidegger, Jean-Paul Sartre and Maurice Merleau-Ponty are some of the most well known. Each of them developed Husserl's basic ideas in their own ways, which is why Herbert Spiegelberg (1994) calls phenomenology a 'movement' rather than a philosophy.

\section{Goethe's phenomenology of nature}

In his historical review of phenomenology Spiegelberg (1994) mentions Georg W F Hegel, but he does not consider the fact that one person of great significance for Hegel's thinking was the famous poet Johann W Goethe (cf Kaufmann, 1993). That Goethe not only wrote poetry and drama, but was also intensely engaged in the study of physical phenomena such as colour (Goethe, 1971), as well as the forms and developments of plants (Goethe, 1960) and animals, is an often neglected fact of Western cultural history. Goethe's scientific method is both intuitive and systematic, proceeding step by step. His theory of colour, for instance, consists of a sequence of experimental observations of light and colour, arranged in a specific order. This order of observed phenomena reflects, he believes, the inherent structure or essence of colour. Thus, for Goethe, there is no gap between phenomena and 
the theory explaining them; phenomena themselves become the theory, provided one discovers how to arrange them in a self-illuminating order or structure.

Hegel was inspired by Goethe's way of doing research, as well as by the epistemology and ontology implicitly hidden in it. The basic tenets of Goethe's epistemology and ontology can be characterised as non-dualism and empirical idealism (Goethe, 1988). 'Non-dualism' refers to Goethe's emphasis on the ontological status of the inner activity and participation of the subject in constituting the object or phenomenon observed; mind is a part of nature and nature a part of mind. The term 'empirical idealism' refers to the subsequent view that ideas and concepts are living experiences rather than purely formal entities. Schieren (1998) develops the pedagogical implications of this position, emphasising how the perceptual power of thinking ${ }^{1}$ is being nurtured and schooled through the activity of perception.

These features make Goethe's way of studying nature a kind of phenomenology avant la lettre. When Husserl's philosophy had become well known, Heinemann (1934) pointed to the similarity between phenomenology and Goethe's approach to the study of nature. Here it would take us too far to go into all the details of similarities and differences between Goethe and Husserl, as recounted by Heinemann. Suffice it to say that Goethe strived 'to preserve the phenomenal datum in its living, unanalysed concreteness' (Heinemann, 1934, p. 69) and that he endeavoured 'to preserve the qualitative aspects of things from dissolution into the quantitative, and to discover its specific character' (p. 80). Goethe resisted the reductionist tendencies of natural science and preserved a genuine interest in actual experience and the many ways in which a phenomenon may appear to us. This may be one reason why the philosopher Ludwig Wittgenstein had a lifelong interest in Goethe's theory of colour and his morphology (Monk, 1991). The biologist Gregory Bateson (1979, p. 25) refers to Goethe in his re-examination of the epistemological foundation of life sciences. More recently some publications have taken up the relevance of Goethe's approach to nature for present times, see for instance Amrine, Zucker, \& Wheeler (1987), Barnes (2000), Böhme and Schiemann (1997), Bortoft (1996) and Seamon and Zajonc (1998). These studies point to the similarity of ideas and perspectives in phenomenology and Goethe's thought.

Goethe and the phenomenological way of studying nature is also of importance for the science teaching in Steiner Waldorf schools, to which we will return below (cf Buck \& Kranich, 1995). In his introductions to Goethe's scientific writings (Steiner, 2000) and his treatise on the theory of knowledge implicit in them, Steiner develops an explicit epistemology of Goethe's way of knowing, focusing on how perception and thinking are entwined in Goethe's research method.

\section{Philosophical phenomenology}

In spite of the similarity between Goethe's thinking and phenomenology, there are of course differences between Goethe's ideas and the philosophy that Husserl developed all through his life. Husserl's project was purely philosophical. His ambition, to which he returned again and again, was to establish an epistemological foundation for all science, including philosophy itself. This made him take up the Cartesian impulse of trying to establish a sort of absolute 'point zero' from which all knowledge could be developed (Husserl, 1973). To put it simply (perhaps beyond recognition), he found this ultimate ground in 'returning to the things themselves', meaning things as given in experience, when this experience is cleansed from all knowledge and suppositions about reality. ${ }^{2}$ The phenomenological researcher must, within her own experience, carry out a 'transcendental reduction' in order to reach that level of experience which is the 'purely given'. This means that ultimately, phenomenology is something you must $d o$, as an inner activity, and it is the reason why Husserl often said that one could 
not really understand his philosophy by merely reading it (there is a parallel with Goethe, who insisted on the necessity of doing his theory of colours, not merely reading about it).

In his posthumously published work Crisis in the European Sciences (1970), Husserl maintained that the scientific culture of Europe has 'fallen' into an uncritical acceptance of Cartesian dualism and its consequent objectivistic and naturalistic views of knowledge. This 'fall' means that science is unable to consider how the subjectivity of the researcher participates in the constitution of scientific knowledge. ${ }^{3}$ For Husserl, one purpose of phenomenological analysis can be said to be the uncovering of this participation by describing the essential correlations between any intentional act of consciousness and the corresponding intended object of experience. In the Crisis Husserl also elaborated the concept of the lifeworld, which has been of central importance for the application of phenomenology in the social sciences. What he actually meant by this concept has been the subject of long debate but, again with the risk of simplifying things beyond recognition, it could be said to mean 'the pre-reflective world of everyday experience'. Husserl's point was that the natural sciences have lost contact with the lifeworld or, more exactly, they no longer realise how scientific knowledge is related to everyday experience and that it in fact always presupposes the lifeworld as its ontological foundation. In his account of Husserl's critique, Harvey (1989) describes Husserl's argument as pointing to an 'ontological reversal', meaning that abstract scientific models are taken as more real than our everyday reality, since the abstract, often mathematical, models are seen as the real causes behind everyday experiences. Husserl did not deny the validity of scientific knowledge, his concern was the acknowledgement of science 'as an idealisation, as a special construction of the theoretical attitude, one remote from everyday experience' (Moran, 2000, p. 12). The relation between lifeworld experience and scientific knowledge is not one of opposition but of continuity. The problem is that this continuity tends to be neglected and forgotten. Furthermore, some of the results of scientific research feed back into the pre-reflective structures of the lifeworld and become sedimented self-evidences of our everyday experience. ${ }^{4}$

As hinted at above, Husserl's philosophy was further developed by his followers, among them his close disciple Heidegger. The relationship between Husserl and Heidegger is a classic topic of phenomenological scholarship (Luft, 2005). Husserl's ambition to make phenomenology into a 'rigorous science' led him into ways of thinking and expressing himself that did not agree with Heidegger's more existential and 'poetic' view of the nature of the phenomenological quest. A further subject of debate is the relation between Husserl and Merleau-Ponty. For the latter, the concept of the perceptual lifeworld is of great importance (Merleau-Ponty, 1962, 1968).

One main difference between Husserl and his followers is that the latter do not adhere to the ambition or even the possibility of establishing an epistemological foundation for all science. Phenomenology nowadays is usually 'postfoundational' (Mensch, 2001). Another difference between the phenomenology of Husserl and that of Heidegger and MerleauPonty is that Husserl - in spite of his motto of returning 'to the things themselves' - is mostly interested in the acts of consciousness in or by which things and phenomena are constituted. Heidegger and Merleau-Ponty, on the other hand, are interested in how things and phenomena come to 'think themselves' in us. Thus, for Merleau-Ponty (1968) perception is a 'nascent logos', that is, a meaning being born in our awareness as if by itself, provided we are attentively present to the thing perceived.

The French philosophers Emmanuel Levinas and Jacques Derrida have contributed to a further, 'post-modern' development of phenomenology (Moran, 2000). These poststructuralist or deconstructivist ways of doing phenomenology have also been applied to science education. In the case of Levinas, the issue of concern is mainly ethical, having to 
do with the relation of human beings to nature and so Levinas has gained an influence on ecological and environmental education (Blades, 2006; Littledyke, 1996). In the case of Derrida, the focus is more on the 'text' of science, in accord with Derrida's thesis that there is no stability of meaning in language (cf Carter, 2004). However, we feel that the issues of concern and the style of thinking employed within these approaches to science education demand a separate and rather extensive treatment, which would exceed the framing of this review.

\section{Anthropological phenomenology}

Phenomenology has had a major impact on anthropology in the last 20 years. The extension of phenomenology formulated by Merleau-Ponty has influenced both anthropology and ethnology. This influence is twofold: on the one hand as an emphasis on 'action before cognition', on the other hand through the focus on culture analysis; seeing the 'meaning of action' and 'experienced meaning' as constituted by the cultural context. In this interpretation, phenomenology provides a shift of focus from a mere cognitive understanding of the world to perceiving and acting in the world. According to Merleau-Ponty, our relation to nature is primarily a doing, not a knowing, relationship. Our consciousness and our ability to think is based on our already being and acting in the world: 'Consciousness is in the first place not a matter of "I think" but of "I can" (Merleau-Ponty, 1962, p. 137). Our "beingin-the-world' is the domain of anthropological phenomenology (Jackson, 1996) and forms a foundation for a phenomenological approach to science education.

The anthropological interpretation of phenomenology emphasises human experience and experiential acting in the world, expressed in our lived experience. Lived experience involves our immediate, pre-reflective consciousness of life and is, as Van Manen (1990, p. 36) proclaims, 'the starting point and end point of phenomenological research'. Researching lived experience implies a radical turn towards life as people experience it in a certain context, a certain culture. Thus, phenomenological research seeks to avoid the reduction of the complex, broad relations between the human being and her environment, because such a reduction would do justice neither to humans nor to phenomena, or to their mutual relations.

Anthropological phenomenology is relevant for science education because it broadens the perspective from science content and natural phenomena to cultures and social relations. This perspective has the same intention as the phenomenology of nature: to let 'things themselves' speak. In relation to science education we might speak of the teacher's double focus in the learning situation: the attention is, on the one hand, directed towards the subject itself, or the phenomena in nature and, on the other hand, towards the students (Østergaard, 2006). Phenomenological culture analysis provides an understanding of both teacher and students as embedded in specific cultural relations, which cannot be reduced or neglected prior to investigation. This interpretation of phenomenology provides an important tool for teachers' self-reflection.

\section{Review procedure and categorisation of phenomenological research in science education}

As can be seen from the previous section, philosophical phenomenology is a kind of 'primary' philosophy dealing with basic questions of epistemology and ontology. As such, it can be applied in many different ways to a complex field like science education.

We started out with an explorative approach to the field of phenomenology applied to science education. Surveying the research literature, however, it soon became obvious that we had to define some specific criteria for selection of studies. In this review the selection 
of studies is based on two main criteria: (1) the studies are strongly empirically grounded; 'empirical' including also reflection on one's own experience (Greek empereia actually means 'experience'); and (2) the studies have a focus on 'doing phenomenology' in relation to learning and teaching science; merely mentioning phenomenology is not enough. In the search process we also found several articles based on phenomenography, which can be seen as a particular interpretation of phenomenology. However, we have chosen not to include these studies in the review, because it is questionable whether such studies can be regarded as 'doing phenomenology'. 5

The phenomenological approach to science education is related to some similar approaches, which we briefly describe here. The constructivist approach to science education is broadly developed and debated. Constructivism is used as a designation for a variety of philosophical and epistemological approaches (cf Matthews, 1998). Educational constructivism stresses the individual formation of knowledge and construction of concepts (Matthews, 1998, p. 3) and has decisively contributed to the shift of focus from teacher-based teaching to student-based learning. One branch of constructivism, sociocultural learning, argues that knowledge construction is inextricably connected to its cultural context (Cobern $\&$ Aikenhead, 1998). This perspective also elaborates on the role of language and its importance for knowledge construction (Resnick, Säljö, Pontocorvo, \& Burge, 1997). According to Matthews (1998, p. 7) constructivism has contributed to science education:

... by alerting teachers to the function of prior learning and extant concepts in the process of learning new material, by stressing the importance of understanding as a goal of science instruction, by fostering pupil engagement in lessons, and other such progressive matters.

Whereas constructivism focuses on cognition and construction of knowledge, phenomenology has a stronger emphasis on the precognitive phase, including the roles of sensing and feeling as different from purely conceptual cognition. Phenomenology agrees that knowledge is constructed by the learning subject and its holistic perspective acknowledges the need to consider learning processes in cultural contexts. However, phenomenology tries to balance the predominance of abstract conceptual explanations by connecting abstract knowledge to being and acting in the world as the basis for genuine understanding. This is in line with Donnelly (1999) who, drawing on Heidegger's major work Being and Time, argues that our fundamental way of being is not cognitive, but rather based on a being-in the world and being-with other people. For teachers this implies that their practice is grounded in a being-with children which is full of care and concern.

Another didactical direction of relevance to phenomenologically oriented science education is context-based learning, having its origins in the early 1980's. This approach to teaching science is characterised by using a specific context as a starting point for developing understanding of scientific ideas (Bennett, Gräsel, Parchmann, \& Waddington, 2005, p. 1522). Context-based learning might, in a narrower view, focus on 'an application of [scientific] theory for the purpose of illumination and reinforcement' (Whitelegg \& Parry, 1999 , p. 68). This is in line with Gilbert (2006, p. 958f) who, regarding context-based chemistry teaching, emphasises contexts as useful for exemplifying concepts from the chemistry curriculum. Context-based learning is similar to the phenomenological approach as they both aim at bridging the gap between lifeworld and scientific concepts. However, they differ substantially in one point, as phenomenologically inspired science teachers tend to regard lifeworld phenomena as the very basis, and not mere illustrations, of scientific knowledge. Thus, in phenomenology one does not search for the suitable context for promoting students' understanding of specific science contents, but rather seeks to develop students' ability to unfold lifeworld phenomena as an entrance into understanding nature. 
The following review of phenomenological research in science education is based on an approximate classification of the various applications by distinguishing between three approaches:

(1) phenomenology of science education;

(2) phenomenology in science education; and

(3) phenomenology and science education integrated.

In phenomenology of science education the processes and activities of teaching and/or learning science are understood and analysed from a phenomenological point of view. Hence, in this approach the student(s) and/or the teacher are focused on; that is, one or two aspects of the teacher-student(s)-subject triad pointed to in the introduction. These studies have a descriptive and/or analytical character, trying to understand what goes on in the teaching and learning of science. Since these are human activities, the studies are often informed by the anthropological phenomenology described above.

Phenomenology in science education consists of phenomenological studies of those natural phenomena that are taken up in science lessons. In this approach the natural phenomenon itself, or the subject taught, is focused on (the third aspect of the triad). Apart from analysing and describing natural phenomena, these studies have also a strongly prescriptive character, suggesting how science ought to be taught. To the extent that they are based on a systematically elaborated phenomenology of nature, they are often informed by Goethe's phenomenological approach to nature.

The third approach, phenomenology and science education integrated, is illustrated by two personalities famous for their work in science and/or science education: Martin Wagenschein, a German science educator in physics and mathematics, and Michael Faraday, well-known English scientist and public lecturer on science. The common trait of these two thinkers is their passionate ambition to grasp 'the whole' of science education, that is, to study and elaborate on the interrelations between the teacher and teaching, the students and learning and the subject taught. To this approach we also count the science education of Steiner Waldorf schools.

In the following we present examples and elements from each of these three categories of phenomenological research on science education. However, it will be obvious that the categories are not mutually exclusive. For example, the studies of science education have more or less explicit consequences for how science ideally should be taught; that is, they have a bearing also on the studies in the second category.

\section{Phenomenology of science education}

The studies in this section can be further classified as focusing on: (1) teachers and teachers' experiences; (2) students as persons; and (3) the activities of learning and teaching.

\section{Focusing on teachers and teachers' experiences}

Baird (1999) reports a study of science teachers' experience of teaching. Baird analysed 12 secondary science teachers' written responses to questions such as 'what is it to be a science teacher?' and 'what is science teaching?' This exercise in phenomenological reflection was regularly repeated over a period of time. The teachers were also interviewed on the basis of their written responses. The purpose of the study was to contribute to the understanding of the nature of teaching and whether the experience of teaching changes over 
time. That the teachers were teaching science thus seems to be incidental rather than of primary interest in Baird's study. Nevertheless the results have some interest from a science education point of view. They show that the teachers experienced two focuses in their teaching activity; the primary focus being the students and the secondary the task of teaching. Hence, the subject taught seems to have been less attended to by the teachers, which is consistent with other studies of teachers' work (Alexandersson, 1994). About one-third of the teachers reported being regularly frustrated and sometimes depressed over their work. These feelings came from experiencing little or no result from their efforts; from the complex and 'poorly defined task' of teaching science; and from working conditions that took too much time away from planning and lesson preparation. The study also indicates that monthly recurring guided exercises in phenomenological reflection helped many of the teachers towards professional improvement. Baird's final conclusion is that schools must 'provide conditions that invite teachers to reflect regularly upon their professional practice' (Baird, 1999, p. 92) in order to develop the quality of their work.

In a study of student science teachers' conceptions of the nature of science, Dahlin (2002) introduced the participants to Goethe's theory of colour and contrasted it with that of Newton. He then asked them whether Goethe's theory was a scientific theory or not. This question was discussed in small groups and the discussions were recorded on video. The analysis showed that most students found it difficult to accept Goethe's ideas as a scientific theory. Their most common argument was that his ideas were too 'subjective'. Thus, these student science teachers assumed the predominant objectivistic stance of scientific knowledge as self-evident and unproblematic. However, a few of the participants did accept Goethe's theory as a science. These students seemed to focus more on the process aspect of science. That is, they emphasised science as a continuous search for new knowledge, rather than science as a product, an established body of objective and true knowledge. This result is interesting, since many studies of science textbooks show that science is most often presented as a product of finished knowledge (see, for instance, Knain, 2001). Controversies within scientific research are seldom, if ever, described, giving the impression that scientific knowledge is non-problematic and consensual (cf Apple, 1990). Another aspect of Dahlin's study is reported in Dahlin (2003); it concerns the so-called ontological reversal mentioned above. Dahlin found indications that the ontological reversal was present as a 'figure of thought' among those students who could not see Goethe's theory of colour as a science. As one student said: 'If there is nothing behind phenomena then there is nothing to investigate'. The context in which this utterance occurred made it reasonable to interpret it as saying that if there is not an invisible but more real world behind our everyday lifeworld experience, then science has no object of study. The conclusion of Dahlin's study was that if phenomenology is to be introduced in science education the preconceptions of science teacher students as to the nature of science probably have to be systematically challenged over a long time. In particular, the inner participation of the subject of the scientific researcher in constituting scientific concepts, models and graphs has to be pointed out. In Husserl's terminology this means repeatedly uncovering the correlations between the intentional acts and the corresponding intended objects (concepts, graphs etc). Through such learning processes, the naïveté of an objectivistic ontology based on the mathematical models of natural science may eventually be realised.

\section{Focusing on the students as persons}

Only one of the studies we found for this review dealt with the more existential questions of meaning, identity and self in relation to science learning; namely that of Kozoll and 
Osborne (2004). The motive behind their study was the fact that science seldom becomes a source of inspiration in students' lives, despite the many hours they spend studying science in school. Since such inspirations often spring from interconnections between experiences and values inherent in the lifeworld, a hermeneutic-phenomenological perspective on the question seems appropriate. Furthermore, the participants in Kozoll and Osborne's investigation were college-aged migrant agricultural workers in the USA. The lifeworld of these individuals is constituted through particular traditions of ethnicity and class, as well as living conditions of poverty and mobility, making it distinct from that of the mainstream US culture. Naturally, this has an impact on these students' relation to education, making them especially prone to dropping out of school.

The study is based on interviews and describes the significance of science in the lives of four students, illustrating four typical ways of relating to science in terms of identity, self and lifeworld. For the first student, 'Hector', science and lifeworld were two mutually exclusive categories. In spite of being 'a mature, thoughtful, intelligent 18-year-old college freshman' (Kozoll \& Osborne, 2004, p. 163), Hector found no meaning in science. Because he had preconceived notions of what science is about and who needs it, scientific concepts and representations of phenomena appeared irrelevant to his life situation. This points to the need for such students to encounter a science teaching which opens up to wider questions of 'beliefs, desires, self, other and world' (p. 166). In such teaching, Hector's feelings about science and about himself in relation to science could be reconfigured, but it requires that science itself becomes a theme in science lessons.

The second student, 'Clara', is characterised as moving 'from lifeworld to identity'. Clara discovered that she could develop a new identity by learning science, but still did not feel completely confident in her abilities. Clara's hesitation had to do with how her achievement in school translated into her view of education as the way to become 'somebody' and leave the life of migration behind.

For the other two students, science took on a clearly significant role in their lives and plans for the future. For 'Andrea', categorised as moving 'from identity to self', the love of science was based on the connection she found between science and nature, which she loved in its own right. She also found that science could connect her to other people. In order for science to appear in such a light for all students, it cannot be presented as an abstract set of unchanging facts and theories. Instead, the authors claim, science teaching must begin with concrete connections to people and to place.

For the fourth student, 'Keith', science, lifeworld, identity and self all came together as a meaningful whole. Keith developed the ability to use science for bringing together disparate contexts to make sense of his experiences and, further, to connect such experiences to other aspects of his life. This gave science a meaning and a place in his lifeworld. One implication to be drawn from Keith's story, according to the authors, is that developing connections to science across contexts can integrate different aspects of students' lifeworld(s). Together with connections to concrete persons, places, identities and self-understandings, such a science education may turn science into a source of inspiration in students' lives.

\section{Focusing on the activities of learning and teaching}

The studies in the previous subsection focused on personal and uniquely subjective experiences of science learning. In this subsection, although the focus is still on experiences (as in all phenomenology), the more general aspects of these experiences are brought forth. The primary aim is not to understand unique individuals, but to analyse and describe the more general features of learning (mostly) and teaching (sometimes) science. 
Based on classroom observations, Szybek (2002) discusses the interactions between what he calls 'the two stages' in science teaching and learning: the stage of scientific knowledge and that of everyday human experience. His analysis ends up in a model of curriculum work involving translations between these two stages. The purpose of the study was to contribute to answering the question of whether science is meaningful, or can be made meaningful, for young students.

The stage of everyday experience is described by drawing upon the Aristotelian concept of causality and Levinas' ethical philosophy. In our everyday life we readily experience and talk about actions and events in a teleological way. We use both effective and teleological causality concepts. Furthermore, following Levinas, the primary modality of everyday actions and events is ethical. In contrast, the only causality allowed in science is the effective one: nature has no purpose. Questions of the ethical values of events are also excluded: nature has no moral values. Since meaning in the existential, phenomenological sense is constituted in the human lifeworld through lived, embodied experience (the everyday stage), in order to be meaningful, the scientific reasoning taking place on the science stage has to be 'translated back' into the lifeworld. ${ }^{6}$ As an illustration, Szybek takes an observation from a science lesson, the purpose of which was to introduce a distinction between plastics that can be melted and those which cannot, related to the question of recycling possibilities. The students heated pieces of plastic with a Bunsen burner. After that the following interchange occurred between the teacher and one of the students:

Teacher: Arash, can you describe what happened with the red piece of plastic?

Arash: $\quad$ It burned. It started to smell. It got black. We couldn't bend it.

Teacher: $\quad$ You couldn't bend it. It was not formable. (Szybek, 2002, p. 541)

This seemingly short and somewhat trivial observation has rich implications from a phenomenological point of view. This is brought out by Szybek through his arrangement of the interaction in a different way (p. 542) (see Table 1).

When the interchange between the teacher and the student is represented as in Table 1, the dramatic difference between the two stages comes to the fore. The student's statements are almost all of such character that they seem irrelevant to that science stage, which relates to the purpose of the lesson. Hence, only one of them is taken up by the teacher, being translated by him into 'it was not formable'. This translation, in turn, elicits no comment from the student (who perhaps does not see the point of it).

As an alternative to the way the observed lesson developed, Szybek suggests that its starting point could be the question of why we need to recycle plastics at all. This could lead to a lot of reasons being brought out, all of them having moral grounds in responsibilities to other human beings and to nature. Next, one could introduce the science stage by asking how to recycle plastic and what we need to know about the properties of plastics in order to effectively recycle it. Then, for instance, the observation that some plastics smell

Table 1. Interaction between teacher and student on the experience of burning plastic.

\begin{tabular}{ll}
\hline Arash & Teacher \\
\hline It burned & No counterpart \\
It started to smell & No counterpart \\
It got black & No counterpart \\
We couldn't bend it & You couldn't bend it \\
No counterpart & It was not formable \\
\hline
\end{tabular}


terribly when burnt may lead to the realisation that the smoke they give off is a healthhazard and that they should perhaps not be thrown away at all, at least not be burned. Thus, there is a 'translation' back and forth between the stage of science and that of the everyday lifeworld:

By participating in a discourse which makes apparent the emergence of science problems from everyday issues the students may see those problems becoming meaningful for them (Szybek, 2002, p. 548).

The importance of participation in meaningful and embodied practices is a recurring theme also in the studies of Wolff-Michael Roth and his colleagues. Roth is the first author of several studies in which phenomenological perspectives are used to analyse learning processes in science education. However, references to original phenomenological works are scarce in these studies and they also draw upon other theoretical perspectives, such as hermeneutics, semiotics and situated learning. A sample of these investigations will be presented here: Roth and Bowen (1999); Roth, Bowen and Masciotra (2002); Roth, McGinn and Bowen (1998); and Roth, McRobbie, Lucas and Boutonné (1997). These authors use phenomenology and other theoretical resources to clarify the difficulties students often have in coming to understand common scientific concepts and representations, such as graphs and tables.

Roth and Bowen (1999) apply Peirce's 'semiotic triad' to students' understanding of graphs in ecology lectures. Peirce's semiotic triad depicts the internal relations between a linguistic sign, its referent and the interpretative act which relates the one to the other, called by Peirce the interpretant. ${ }^{7}$ A graph is obviously a particular kind of sign used to represent correlations between factors of relevance for the understanding (the interpretant) of a natural phenomenon (the referent). Here, Roth and Bowen (1999) develop the semiotic triad of sign-referent-interpretant. They do so by regarding the relation of the interpretant to the sign as hermeneutical (understanding of linguistic signs and discourse); and the relation of the interpretant to the referent as phenomenological (direct perception and experience of phenomena). Their basic conclusion is that whereas the ecology lecturers could draw upon rich hermeneutical and phenomenological experiences; that is, experiences both from the discursive practices in which graphic representations are an important element and from field studies of the actual phenomena, the students lacked both of these. It is therefore only natural that the students have difficulties in constituting the relations between signs and referents when trying to understand various graphical representations.

In Roth et al. (2002) the focus is also on learning to understand graphs. The participants in this study were pre-service elementary teachers with an emphasis on science teaching, college science graduates and practising scientists. The development of graphical understanding could roughly be described in three stages: at the lowest stage the graphs never became signs referring to anything beyond themselves, i.e. the reading/interpretation was stuck at a level where the sign/graph becomes its own referent. At the next stage there is a structuring reading activity that subsequently relates the graph to a description of natural phenomena. At the third stage the graph itself has become transparent, giving straight access to the objects signified. Such transparent readings of graphs:

... are always associated with the co-presence of signified objects and signifying text in the life world of the individuals who integrate both in their ongoing work and therefore through their habitual practices. (p. 350)

Naturally, these practices were habitual parts only of the lifeworld of the scientists involved in research. However, even for them it was sometimes difficult to read and understand graphs 
from fields other than their own discipline. When confronted with graphs from an unknown field, scientists sometimes fell back to earlier stages of development. Consequently, the ability to look through the graph to the reality represented requires a prolonged period of 'situated practice' in which both the discursive (hermeneutic) and the perceptual (phenomenological) dimensions of graphical representations become habitual lifeworld elements. In this process there develops the dialectic ability to move 'from the world as understood to graphs, and from a structural reading of graphs to possible worlds they might represent' (p. 352). Insight into this dialectic counteracts the misconception of graphs as somehow isomorphic to the structure of the world; that is, as built on an essential one-to-one correspondence between graphical elements and world structure. This in turn may dissolve the positivistic illusion of scientific representations as somehow objectively given.

The results of these two studies are important for science education. For one thing, many textbooks seem to adhere to the positivistic illusion of isomorphic objectivity, as well as to the belief that the meaning of a graph is somehow 'obvious'. Another implication is that there is no immediate answer to the chicken-and-egg type of question of whether to start with teaching the graphs or with pointing to the phenomena themselves, 'other than that some sort of bootstrapping process allows both to emerge and co-evolve' (Roth et al., 2002, p. 352).

Roth et al. (1998) investigated the question of understanding graphs and tables in the context of teacher education. Considering that pupils are now expected to learn how to analyse data, tables and graphs as early as in the elementary and intermediate grades, preservice science teachers must also develop this ability. Participants in the study were teacher-students who had either an undergraduate or a master's degree in science. Given a set of data that ideally called for a transformation into a graph or a table, only $47 \%$ of the participants carried out such a transformation. Thus, many of them did not see the pattern in the data, which was actually there. When they rejected any kind of correlation between variables, they did so on the grounds that data closely associated in space seemed to point in opposite directions. The authors maintain that:

... the ontology underlying such an argument holds that nature is governed by mathematical laws and that deviations from the ideal relationships are due to measurement errors and unmeasured mediating factors [...]. (p. 43)

The authors also point out that this ontology is fostered by textbooks that portray phenomena in idealised graphical forms that have little to do with the original data gathered from systematic observations. It seems that this is an aspect of the 'ontological reversal' described above (Dahlin, 2003); that is, mathematical idealisations are considered more real than perceptual lifeworld experience. As a consequence, that which does not conform to such idealisations is discarded as irrelevant from a scientific point of view. There seems to be a lack of attention to the genetic aspect of various forms of scientific representation, whether conceptual or graphical. That is, teachers must realise that conceptual and graphical representations - sometimes even phenomena themselves - are brought forth through various kinds of actions and practices in the laboratories of scientific research. ${ }^{8}$ Lacking this realisation, science education becomes full of multifarious forms of Husserl's 'sedimented self-evidences': things that are taken for granted without really being understood. Roth et al.'s solution to this problem is to involve pre-service science teachers in 'communities of practice' similar to those of real scientists. This solution is in stark contrast to the most common form of science teacher education, where the students are informed of scientific facts through reading textbooks and listening to lectures. 
Someone may object that laboratory work is also an essential part of science teaching and then the students are actively reasoning and interpreting the phenomena they produce. However, students do not seem to learn as much from laboratory activity as expected or desired. This is both the starting point and the outcome of the study reported in Roth et al. (1997). The purpose of the study was to understand why this is the case. In order to do this, the authors claim that:

... one needs to view classroom activities from the perspective of someone who does not yet know. This is a methodological move characteristic of phenomenology. (p. 110)

One aspect of laboratory work usually not considered by science teachers is the necessity to discriminate between 'blotches' and 'wiggles' on the one hand and 'real signals' on the other. The distinction between a 'real signal' and an irrelevant 'blip' has to be rationally accounted for. This is part of learning to see a laboratory phenomenon. ${ }^{9}$ The high school students in Roth et al.'s (1997) study had not learned to evaluate the significance of variations in observed phenomena; hence, they could not discriminate between random errors and significant variations. Neither did the teacher guiding the laboratory work, who was recognised by his peers as a very competent science teacher, seem to consider the necessity to develop this ability. When students' observations did not conform to the canonical understanding of physics, the teacher did not use the situation as an opportunity for learning:

... but said that the events observed were due to unevenness of the table or the objects themselves, without even investigating whether his suggestions made sense ... (p. 131; our italics)

Furthermore, science teachers often misjudge the relation between experiment, observed phenomena and theory in that they do not consider how phenomena in the laboratory are produced by student activity. There is no guarantee that the phenomena produced, observed and interpreted by the students are the same as the canonical phenomena of science that the teacher wants them to observe. From the phenomenological perspective:

... every interpretation emerges from the interaction of the 'horizon' individuals bring to the situation and the 'horizon' of the text/thing. In this interaction, world is divided into foreground and background. This foregrounding brings out the aspects of the thing, the particular understanding of the text the individual looks at. Because students 'put their minds on' to make sense of observations these are in most cases not those of scientists. (pp. 130-131; italics in original)

Roth et al. (1997) suggest that instead of rejecting or neglecting students' non-canonical observations and interpretations, teachers need to establish forums in which the diversity of interpretations can be discussed and contrasted with the canonical views, which the teacher may have to contribute him- or herself.

\section{Phenomenology in science education}

This section deals with research using phenomenology as a pedagogical approach to various phenomena of nature. One might think that phenomenology could be well suited for more global educational areas, such as environmental studies, but not for the cut and dried facts of a hard science like physics. However, Arons (1982) clearly points out the pedagogical possibilities inherent in a phenomenological approach to some physical phenomena related 
to electricity and magnetism. The fast pace with which subjects are usually covered, and the consequent lack of essential phenomenological procedures such as careful observation, description, reflection and discussion of various interpretations of perceived phenomena, contributes to a lot of misunderstanding and non-effective learning on the students' part. One of Arons' examples is the demonstration of how two wires carrying electric current in the same direction attract each other. This phenomenon is almost invariably asserted to be 'electromagnetic', without reference to any other a priori possibility. Yet, when seen for the first time, without knowledge of the scientific canon, it could also be interpreted as electrostatic. In fact, Ampèrè, who was the first to write about the phenomenon, had to use more than one page to convince his readers that it was not electrostatic, but of a different category. What were his arguments? How could he distinguish between this phenomenon and electrostatic ones? He must somehow have perceived the difference, but this crucial fact is lost on the students. It means the loss of a valuable pedagogical opportunity to point out two important aspects of scientific thought:

... (1) that we should raise the question as to whether we are really confronting a new phenomenon or merely some subtle variation of one already known; (2) the opportunity to think qualitatively and phenomenologically about the two possible interpretations, distinguish between them operationally, and fix them in a richer perspective in one's own mind. (Arons, 1982, p. 13)

Not only has the way of teaching, that is, the knowledge presentation, to be changed, but also the forms of testing and assessment. According to Arons, assessment questions should more take the form of 'How do we know that ...?', 'Why do we believe that ...?' or 'What is the evidence for ...?'. This is an important insight, since it is well known that one of the most powerful ways of changing students learning strategies is to change the forms of assessment (Biggs, 1999).

Another study dealing with the hard facts of physics is that by Freudenthal (1993). In the vignette to his article, the author says:

If it is true - and who can deny it? - that in mechanics instruction body experience interferes inconveniently with scientific ideas, then it is of paramount importance, instead of suppressing them, to have the learning processes started just there, and the learner, under guidance, transform them into what we consider scientific. (p. 71)

This principle for teaching and learning is in accordance with phenomenology in that it strives to 'ground' scientific concepts in concrete lifeworld experience. In his article, Freudenthal proceeds to describe a number of examples of how this principle could be applied in teaching the concept of force. Freudenthal suggests muscle experiences in for instance pushing or tugs-of-war as points of entrance into the conceptual field. His discussions are difficult to summarise within this review; suffice it to say that they contain many valuable insights and suggestions for a phenomenological approach to teaching mechanics.

In our view, Freudenthal's approach has a parallel with the 'epistemology of physics' presented by diSessa (1993). According to diSessa, children's learning of physics ought to start from what he calls 'phenomenological primitives', or 'p-prims'. P-prims are loosely connected ideas about the world, linked to and cued by concrete experiences and observations of phenomena. They are not general and abstract as scientific concepts, but, in spite of their limited applications, they seem self-evident and unproblematic. A possible example would be the idea of 'doing work' or 'spending energy' when hanging still from bent arms, although from the point of view of mechanics there is no energy spent unless you move your 
body. diSessa's point is that learning science means the refinement of such p-prims, not their abolishment or replacement. For this to happen, the p-prims have to be carefully taken up and developed in the teaching process, not neglected, denied or declared meaningless and untrue.

In the study reviewed above, Freudenthal (1993) also notes that it took a long time for physicists to agree on the exact definition of the force concept. This points to the significance of the historical dimension of science. History of science can actually contribute a lot to phenomenological science teaching, as Bevilacqua and Gianetto (1995) argue. From a hermeneutic-phenomenological point of view, 'teaching physics has to be connected to teaching history of physics, that is physics within the historically determined lifeworlds that give rise to its practices' (pp. 120-121). The history of (any) science is full of 'alternative interpretations' of phenomena (what today are often called 'misconceptions'), and these 'have to be outlined and clarified, not hidden and mystified' (p. 120). In common with many other phenomenologists, Bevilacqua and Gianetto are concerned with building a bridge between the lifeworld and the 'science world' and they suggest that one starting point for this bridge construction could be the study of 'the transition from an empirically grounded physics related to lifeworld experience to an experimentally grounded physics' (p. 122) in the seventeenth century. ${ }^{10}$

In a recently published thesis in physics, Grebe-Ellis (2005) develops a phenomenology of the polarisation of light. The methodological approach in this work is in line with Goethe's (1971) theory of colours and Mackensen's (1981) notion of model-free optics. Grebe-Ellis' study is about methods for describing the 'optics of images' as opposed to abstract and nonexperiential optics. He addresses the problem of teaching optics where the phenomena are abstracted from the context of students' sense experiences. Even though Grebe-Ellis has no explicit focus on how students perceive light and optical phenomena, he draws a line from the question 'what is light?' to 'what do we see?' and further to 'what are the prerequisites for our seeing?' (Grebe-Ellis, 2005, p. 22; italics in original). This suggests the inclusion of reflection on students' sense experiences as part of teaching optics.

Going from physics to chemistry, a perhaps less dry but still hard science, Soentgen (1997) develops a phenomenological understanding of the concept of substance and substance processes or material change. In order to distinguish '[material] substance' from 'non-substances', Soentgen defines a set of descriptors that indicate that substances appear to be more related to what could be called 'organic nature' than what is usually thought. This contribution is aiming at a more elaborate reconstruction of basic concepts in chemistry, for instance that of material change. As an example of the pedagogical use of this reconstruction, Soentgen points to the following situation in chemistry teaching: a teacher wants to introduce the concept of 'dissolving of substances' and for this purpose she pours grains of salt into a test tube with water. The tube is shaken until the salt is completely dissolved. The students are shown the fact that the salt is dissolved. However, the highly complex process of the salt undergoing dissolution is totally overlooked. This process of transformation, Soentgen argues, should be made explicitly conscious to the students as an essential part of chemical phenomena. Referring to the work of Soentgen, Kranich (2005a, p. 22) points out the difference between mere observation of appearances in chemistry, for instance the properties of different elements, and the inner sense-making activity of seeing the transformations, interplay and dynamics of forces at work in chemical phenomena. This 'perceptual power of thinking' must, however, be practiced - as in the case of Goethe - in contact with sensing and reflecting on living phenomena.

We end this review of phenomenological studies of natural phenomena taken up in science lessons by referring to the numerous textbooks and studies that are informed by 
Goethe's phenomenological approach to nature (see above). This literature is to a large extent connected to Steiner Waldorf Schools (see below) and covers a broad field of subjects within science teaching; as for instance optics and light, represented by Julius (1984) working on the phenomenology of light, and Zajonc's (1999) Catching the Light, or in chemistry, represented by a whole series of different textbooks as Chemistry Taught by Phenomenological Method (Ott, 1960, 1962) and Julius' (1988a, 1988b) two volumes on Foundations of a Phenomenological Chemistry. Many publications in more specific fields of chemistry, as for instance Starch, Proteins, Sugars and Fats (Mackensen, 1987), have been developed at the educational research institute connected to the association of German Waldorf Schools. The literature related to science education in Waldorf Schools is quite extensive, covering a broad time span from Kolisko (1932), who wrote the first outline of a phenomenological curriculum in chemistry, to the detailed phenomenological exposition of how to understand chemistry (Kranich, 2005b). It also covers a wide range of scientific fields, from biochemistry (Wolf, 1998), through genetics (Holdridge, 1996) and embryology to botany, zoology and ecology. The common hallmark of these works is an aesthetically rich knowledge formation through 'genetic and exemplary' (see below) approaches to natural phenomena by letting 'phenomena themselves speak'. Studies within this tradition with a more explicit view on the students' learning processes will be reviewed in the next section.

\section{Phenomenology and science education integrated}

In the two previous sections we have reviewed research, which has a main emphasis on either the process of teaching and/or learning science or on reflections on natural phenomena that are taught in science lessons. In this section we will describe the work of two phenomenologically oriented science educators, Michael Faraday and Martin Wagenschein. In both of them phenomenology is integrated in the subject taught as well as in the teaching design. We will then proceed to a more thorough description of the science education in Steiner Waldorf Schools.

\section{Michael Faraday and the chemical history of a candle}

Michael Faraday (1791-1867) is well known as a brilliant experimental scientist from the nineteenth century. Maybe due to his almost complete lack of formal education and his entrance into science through pure apprenticeship under Sir Humphry Davy, his whole approach to science was purely experimental, 'letting nature herself speak' and 'learning to read in the book of nature'. ${ }^{11}$ In his best-selling biography on Michael Faraday, David Hamilton (2000) stresses the uniqueness of his experiential approach to understanding, where his method of discovery is a direct coupling of extraordinarily precise observations with an extraordinarily dynamic imagination:

Faraday thought in images, and would be glad to proclaim a successful result 'beautiful', and an understanding of the roots of his imagery and the process of image-making may lead to a deeper understanding of him as a man ... His experimental results were reached not by theory and calculation but by observation of physical and visual effects, using instruments of his own devising. (Hamilton, 2000, p. xix)

It is along this experiential pathway of coming to understand nature that Faraday later builds his philosophy and practice of science education. He develops his quite original style of teaching based on a composed series of natural phenomena. Like in theatre, it consists of 
movements from scene to scene directing the attention of the audience, building up their own living images and connections from seeing the story unfolding on stage. This manner of teaching the latest findings of physics and chemistry to non-scientific audiences was developed over a series of years (1827-1860) in the lecture hall at the Royal Institution in London. In an interview, probably given after the electricity juvenile lectures in December 1829, Faraday offers an interesting answer to the journalist's question: 'Sir, I am told you come from a poor family. How is it that you came to desire an education?':

My father was a blacksmith, and there is much chemistry in smithing; I would dare say a great deal of science ... Indeed the purpose of my lectures, simple and plain as they are, is to show my audience how wonderful it is to observe. Indeed the best members of my audience are children. They just watch, and very little escapes their awareness. I hope in the future to present Christmas lectures for the juvenile audience. Maybe you could come to observe their wonderful uninhibited behaviour. (Faraday, 1990, p. 2)

Faraday's philosophy of science education is in many ways contained in this quotation. What he states here is a clear linking of science education to practical knowledge and to cultivation of observational skills. It is, in other words, a phenomenological approach. And it has a double face: one towards cultivation of the skill of observing nature and the other towards the cultivation of the skill of observing the child.

For years Faraday worked to improve his delivery, presenting Christmas lectures to the juvenile audience. The last of these lectures was held thirty years later, in 1860. The title of the lecture was The Chemical History of a Candle (Faraday, undated). It is a surprisingly simple phenomenon, a candle, that is put in the centre of the six days of lectures. And Faraday explains right at the beginning of the lectures the reason for his choice:

There is not a law under which any part of this universe is governed which does not come into play, and is touched upon in these phenomena. There is no better, there is no more open door by which you can enter into the study of natural philosophy, than by considering the physical phenomena of a candle. I trust, therefore, I shall not disappoint you in choosing this for my subject rather than any newer topic, which could not be better, were it even so good. (Faraday, 1990, pp. 13-14)

Everything is there, it is only a matter of seeing it. In revealing what is there, Faraday demonstrates the art of composing a genesis of understanding. The key of structuring is to follow the 'storyline of the phenomenon itself', beginning on the first day in the solid stearin, moving, day by day, into the liquid (the 'cup'), up through the wick into the flame, ending on the sixth day with the final chemical products of the combustion and the ecology related to these substances. The composed series of natural phenomena are structured not by Faraday, but by the phenomenon itself. Faraday's role is to make this secret visible, imaginable and understandable. It is interesting to see how this approach to teaching science also implies a different evaluation of what it means to be uneducated:

It seems the children are most interested and unassuming. They do not know anything about science and therefore have very open minds. They seem to grasp the purpose more quickly than many learned adults. (Faraday, 1990, p. 2)

According to Faraday's philosophy, understanding arises in dialogue with nature and with the students in the audience. His role is to help nature herself speak and to help the audience themselves understand what is spoken. Through this style of 'discovery and instruction', Faraday unveils the aesthetic dimension of science and science education. Charles Dickens, 
who was in the audience and who saw this aesthetic dimension, was so thrilled that he asked Faraday permission to publish his lectures (Hamilton, 2000).

\section{Martin Wagenschein's phenomenology of science education}

Martin Wagenschein (1896-1988) fought passionately against the division of the world into a part that can be sensed and experienced and a theoretical part, described with models and abstract concepts (Flitner, 1990). In his phenomenological approach to science education, he claims that the main problem in current physics teaching is that it is planned from the end: starting with the basic concepts and the mathematical structures of physics to be learned, the teacher aims to make it understandable for the learner, adding experiments, as mere illustrations. Wagenschein has the opposite point of departure, using experienced phenomena as points of entrance into the world of scientific knowledge. He even goes one step further, pointing to the value of letting the concepts of physics be challenged through an encounter with phenomena of nature (Wagenschein, 1990).

After World War II Martin Wagenschein developed his concept of genetic-socraticexemplary teaching and learning (Wagenschein, 1968). These three concepts denote three aspects of one teaching method, aimed explicitly at what he refers to as 'Verstehen lernen' - learning how to come to understanding. The genetic aspect of the method emphasises that the learner should be given the opportunity to start with his or her own personal knowledge and experience and therewith generate conceptual understanding. This aspect particularly focuses on how knowledge and understanding develop from attentive activity within, more than simply accepted instruction from outside. From a teaching perspective it focuses on how conceptual knowledge in science can grow out of the world of the senses. The socratic aspect implies a focus on dialogue as a crucial element of any genuine learning process. The role of the teacher is the one Socrates adopted: helping the student to develop their own understanding by intentional questioning. The third aspect, exemplary, emphasises the fact that real-world examples must be carefully chosen for the teaching situation and that the selected examples should be dealt with in depth. This exemplary approach to learning science presupposes that the whole can be traced in the particular (Wagenschein, 1968, p. 12); that - as in the case of Faraday's candle - the general is found in the unique.

Wagenschein's concept of wholeness is typical for his approach to science education. The wholeness is not merely connected to the wholeness of the science subject, for example physics, but in favourable cases also to the learning person (Wagenschein, 1968, p. 14). Wagenschein argued that an emphasis on students as whole persons is important:

... not only in order to promote their ability to memorise facts, but because teaching can encourage the students' educative experience and their confidence in the world. (p. 17; our translation)

The learning processes are, according to Wagenschein, intimately connected to processes of becoming - becoming a human being and, within this context, the growth of understanding and knowing. When Wagenschein again and again refers back to the method of Socrates, it is because this process of becoming 'is most efficaciously promoted in dialogue' (p. 55).

The theory and practice of Wagenschein has inspired several researchers, for instance Peter Buck $(1986,1997)$ who discusses epistemological issues in learning to understand natural phenomena. ${ }^{12}$ Buck (1986) elaborates on students' ability of transformative thinking. He argues that this ability of transformation is an analogue to the processes in chemistry 
where we consider magnesium oxide as a transformation product of magnesium and oxygen.

This explicit double focus, on the dialogue with natural phenomena on the one hand, and on the student and his/her attentive activities on the other, is Wagenschein's unique contribution to science education. What appears implicitly in Faraday as mastery appears in Wagenschein as an explicit, coherent theory of learning and teaching science.

\section{Phenomenological science education in Steiner Waldorf schools}

Since it's beginning in 1919, the Waldorf School Movement has an almost 90 years old tradition of cultivating a phenomenological approach to science education. Building on Goethe's phenomenology, ${ }^{13}$ Steiner (2000) attempted to create a bridge epistemologically between the artistic and scientific approach to understanding nature.

According to Manfred von Mackensen, a leading German Goetheanistic teacher and researcher, science education has a very central position in Waldorf Schools (Buck \& Mackensen, 1980), particularly in balancing the strong emphasis on artistic subjects. The aim of science education is to strengthen the interest and ability to observe, and to promote students' 'thinking in qualitative transformations' (p. 11). Taking chemistry as an example, the typical Waldorf curriculum is throughout exemplary, in Wagenschein's sense. Building on the work of Kolisko (1932), Ott $(1960,1962)$ developed a textbook for teachers of chemistry based on a phenomenological method from grade 7 through upper secondary. One phenomenon builds on the other; from the process of combustion to oxides, from the oxides to acids and bases and from them onwards to chemical salts. The main focus is on chemical phenomena and not on what takes place in the teacher and learner. However, Julius (1988a) develops all three areas entwined, including the exemplary, genetic and dialogical aspects of teaching chemistry, rooting it back in Steiner's pedagogical impulse. In Kranich (2005b), a rich picture of the properties of chemical elements is developed and linked to an understanding of the ecology of their appearances in nature. This perceptual connection from the world of chemistry to the lifeworld of visible natural phenomena is possible through deepening the 'perceptual power of thinking' about chemical elements, compounds and processes (Kranich, 2005a). The link from phenomenology to science depends, according to Kranich, on such aesthetic schooling of seeing the forces behind the appearances:

If a phenomenological chemistry should be science, in the modern meaning of the word, then it has to be extended from the appearances of the substances to the interplay of those forces they are born out of. (p. 16; our translation)

Since this tradition of science education has lived outside public schools and the literature is confined to the German language, it is little known. In the field of teacher training, a phenomenological approach, building on the tradition of Faraday, Wagenschein and Waldorf school education, has lately been developed by Hugo (2006), connected to educating teachers in agricultural and natural sciences at the Norwegian University of Life Sciences.

The science teaching of Steiner Waldorf schools in the USA has recently been evaluated by Jelinek and Sun (2003). Among other things, the results of Waldorf and public school students on three different test variables were compared. Two tests measured verbal and non-verbal logical reasoning, respectively, and the third test was a task from the TIMSS test (about magnetism). The results for the Waldorf schools were better than 
those for the public school on the non-verbal reasoning task and on the TIMSS task, but about the same for the verbal logical reasoning task (on the TIMSS task the Waldorf group results were also higher than the international average). Concerning the two logical tests, the authors note that the results indicated that when the tasks 'involve partwhole-relations, the Waldorf group outperformed the public school group' (p. 43). The evaluation also included videotaped observations of Waldorf science classes. It was found that a lot of lesson time was spent on asking questions, considering possible answers to questions, noting unexpected phenomena and carefully observing specific phenomena (p. 49). These activities are in accordance with a teaching approach based on phenomenological principles. On the other hand, very little time was spent on exploring the differences between students' perceptions and considering different answers and solutions, which also could be expected in a phenomenological teaching approach. On the positive side the researchers also noted a high degree of enthusiasm for science among the Waldorf students. On the negative side, the science curriculum for Waldorf schools was considered somewhat old-fashioned and out of date, as well as including some doubtful scientific material.

\section{Discussion}

In this section we will first sum up and discuss the main themes reflected in the reviewed literature. We will then try to formulate some further possibilities of connecting phenomenology and science education; possibilities which still to a large extent await realisation.

\section{The main themes}

The general and prevalent concern for almost all of the studies reviewed is the question of how to help students bridge the gap (which is there in spite of the underlying continuity) between the lifeworld and the 'science world'. This seems to be the common core of phenomenological critiques of mainstream science education. Various concepts and metaphors are used to describe the gap between these two worlds, such as 'two stages', 'p-prims' and 'reductive idealisations'. In some studies the gap is formulated in terms of science versus society and culture, in others more in terms of science versus immediate perceptions and experiences of natural phenomena. In both cases the underlying assumption is that the 'science world' and the lifeworld are too far apart and that this is a major cause for the difficulties students have in learning science. Is this assumption justified? We believe it is. For one thing, scientists themselves seem well aware of the counterintuitive and noncommonsensical nature of scientific knowledge; see for instance Wolpert (1992). Empirical studies also show how most students experience science as 'not for them' (Jenkins \& Nelson, 2005), indicating an alienated distance between themselves and the 'science world'. An important point to make in the phenomenological critique of mainstream science education is to emphasise that sensing is not in opposition to cognition - it is rather an entrance into a deepened performance of 'the task of abstraction' (Wagenschein, 1983, p. 109; our translation).

Our first category, phenomenology of science education, encompasses a broad field of studies focusing on teachers, students and teaching/learning activities. In relation to teachers and teaching, Baird (1999) showed that the primary focus of teachers' awareness was either the students or the teaching task. Hence, the subject taught was more or less taken for granted as a kind of given background. The result of Dahlin's (2002) study indicate the 
same thing: scientific knowledge is not seen as problematic but as a kind of finished 'body of knowledge' to be delivered to students. If teachers are to apply a phenomenological approach to teaching science, perhaps the best way (in terms of least resistance) would be to start reflecting on students and what it means to teach and then to move on to the subject taught as a second step. As for students, one overriding theme seems to be the question of how to develop connections to science across contexts that can integrate different aspects of students' lifeworld(s) (Kozoll \& Osborne, 2004). Szybek's (2002) suggestion to start a series of lessons with the question of why we need to recycle plastics is a concrete illustration of how this might be done.

When it comes to teaching and learning activities, the studies of Wolff-Michael Roth and his colleagues point to the utter importance of the genetic aspect of knowledge, whether in the form of concepts or of graphs. This aspect is also part of learning to perceive a particular laboratory phenomenon. The genetic aspect of knowledge is a central theme also of Wagenschein's (1968) phenomenological science education. Indeed, it is a central theme of phenomenology in general (Merleau-Ponty, 1968). How does knowing happen, how does the process of knowledge constitution take place? Such questions seem to be neglected by many teachers and phenomenology can help to bring them into focus. However, when this neglect is coupled with the textbooks' positivistic illusion of isomorphic objectivity, i.e. that the meaning of a purely factual text or a graph is somehow 'obvious', students' learning is likely to move in unforeseen and less desirable directions. Nevertheless, important as these considerations may be, none of the studies reviewed here have tried to establish that using phenomenological teaching methods really enhances students' learning.

In our second category, phenomenology in science education, we find many science teachers and science education researchers engaged in making science and nature less strange and alienating to students, as well as in improving students' understanding of scientific concepts and theories. A recurring theme is a resistance to the haste with which traditional teaching classifies and conceptualises phenomena, without considering for instance the historical process leading up to the presently established scientific view. In a way, this theme is analogous to that of the genetic aspect of knowledge discussed above. Looking more carefully at what diSessa (1993) calls the phenomenological primitives of a specific concept, or the process of interpreting an electromagnetic phenomenon (Arons, 1982), or our varied everyday experiences of force (Freudenthal, 1993), we resist what Goethe called the wild coupe of theory, i.e. the quick and superficial classifying or categorising of things, without really seeing. Arons' (1982) suggestion to put examination questions like 'what is the evidence for our theory that ...?' is an excellent practical implication of a more phenomenological approach to science teaching.

The main part of this second category comes from the Steiner Waldorf school tradition and the heritage of Goethe. One overriding theme within this tradition is to teach science in such a way that a sense of meaningful wholeness of nature grows in the students; a wholeness from which the human being is not separated or alienated. At the same time, the concepts of science must also be clearly and precisely delimited. However, in our view students' learning processes cannot be organised through a purely phenomenological turn to the phenomena of nature. The learning situation must also be taken into account.

The last category, phenomenology and science education integrated, contains works marked by the intention of doing phenomenology in a learning situation. As science teachers, Wagenschein and Faraday design the learning situation with emphasis on both natural phenomena and students as concrete persons with their own experiences and life histories. 
The interrelations between teacher and teaching, students and learning, and the subject taught are elaborated upon (as also is the intention of the science education of Steiner Waldorf schools).

We found few studies that discussed the concept of phenomenology in relation to science education. The term 'phenomenological' often referred to an open, pre-conceptual approach to phenomena used in science lessons. For instance, Grebe-Ellis (2005) uses 'model-free optics' and 'optics of images' as essentials of his developed phenomenology of optics. Buck's (1996) elaborations on the use of the term 'phenomenological' in studies of chemistry education can be of help here. Buck claims that the term 'phenomenological' is used in multiple ways without being explicitly defined. In chemistry education, Buck finds three different meanings of the term: (1) as 'introductory efforts', as used by Wagenschein; (2) as 'theory of knowledge and cognition' as used by Husserl, and (3) as 'chemical phenomenology' or 'Lerninhalt', i.e. as the actual content of teaching and learning (p. 50). These three uses of the term can be found to various degrees in the studies reviewed above. Phenomenology in the first sense is probably most commonly used by natural scientists with an educational or pedagogical interest, as illustrated by Arons (1982), diSessa (1993) and Freudenthal (1993). Phenomenology as theory of knowledge and cognition comes clearly to the fore in the studies of Wolff-Michael Roth and his colleagues, albeit not in a 'pure' form because it is mixed also with other elements from, for instance, the theory of situated learning. It is also the basic perspective in the study of Szybek (2002). Finally, phenomenology as 'Lerninhalt', the most radical use of phenomenology in science education, is most common in studies based on the Goetheanistic and Steiner Waldorf approach to science education.

\section{Potentials of phenomenology in science education}

Our review of existing research on phenomenology and science education motivates us to point to the necessity of further research. Considering the two aspects of the present crisis in science education: students' disinterest in science subjects and the inability of many students to achieve understanding of subjects in science - what has phenomenology to offer? As indicated in our introduction, three entrances may be pointed out for research in science education: the teacher, the students and the subject taught. In phenomenological science teaching, the teacher has to approach all three: on one side the understanding of nature or the subject taught, on the other the students and their learning activity - and on the third, connecting the two, his/her own teaching and self-reflection.

Hence, one area for further research is the question of how to introduce teachers to both the phenomenology of nature and of teaching and learning practices. Faraday and Wagenschein both built their own phenomenological foundation through years of reflective teaching practice. How could a similar process be introduced within the framework of formal teacher training in science education? What are the key competencies that such a teacher training should cultivate? And what implications can be drawn for shaping teacher training in science education?

Another question is whether (and in what ways) phenomenology actually enhances science learning and promotes students' thinking in science. None of the studies referred to above have investigated the learning effects of phenomenologically-based science teaching, let alone compared them with the effects of non-phenomenological teaching approaches. The only empirical data we have regarding such effects is the above-mentioned evaluation of Steiner Waldorf schools in the USA. The results of that study indicate that more systematic investigations could be worthwhile. However, many of the textbooks and studies 
written by researchers and educators from the Steiner Waldorf schools also refer to positive experiences with science teaching based on phenomenology (see for instance Buck \& Kranich, 1995; Kranich, 2005b; Mackensen 1981). These reports indicate that more systematic investigations could be of importance.

A third area for research is connected to the question of how phenomenology may help to bridge the gap between the lifeworld and the 'science world' in science education. One question is whether teachers' attitudes towards science subjects change when using phenomenology to connect scientific concepts with the lifeworld of the student? Another question is whether/how teachers' understanding of the learning student changes as they turn to using phenomenological methods for studying natural phenomena? These questions belong to the integrated approach to phenomenology and science education since they focus on interrelations between the teachers' activity of teaching, students' activity of learning and the substance of the subject taught.

A fourth area, connected to the other three, is the clarification of the relationship between the phenomenological approaches and the idea of science as true knowledge. Is Goethe's theory of colour as true as Newton's theory? How does lifeworld experience as we find it described in philosophical and anthropological phenomenology relate to concepts of true scientific knowledge? A clarification of these issues demands a differentiation of various stances within the field of phenomenology. This opens up a whole new field of ontological and epistemological discourse, which transcends the scope of this review article.

In conclusion, phenomenology has a considerable potential as a method for investigating learning as a whole. According to Lukenchuk (2006), phenomenology is a way to connect the theory and the practice of science education. Our review shows that phenomenology and science education meet most fruitfully when phenomenology is done, when it is turned into actual efforts for understanding and promoting learning. Phenomenological critiques of current science education are interesting because they insist on lifeworld and natural phenomena transcending scientific knowledge: scientific knowledge is one way to understand the human lifeworld, not the way. As Van Manen (1990, p. 29) notes, phenomenological research always begins in the lifeworld and, because phenomenology is discovery oriented, it can be a tool for illuminating 'paths towards a clearing' (Heidegger). Our exposition of phenomenology in science education has provided an overview of a landscape of research activity; a landscape in which we see various streams with different sources and with various meeting points. We can see harvested fields, where different areas of science education have been cultivated over a long time. In other areas we see only beginning clearings in the thick forest, where new fields are being opened. The overall picture that emerges is a valley where cultivated fields and clearings are scattered here and there. Only a few pathways are connecting the different pioneering activities and only small villages can be traced, where a culture of inquiry is taking place. To the mainstream researcher in science education, along the main river on the other side of the mountains, phenomenology in science education seems to be a not-yet-discovered valley of their world.

\section{Notes}

1. The term 'perceptual power of thinking' is Schieren's (personal communication) own translation of Goethe's original concept 'anschauende Urteilskraft', which Goethe used to describe the essence of his own method.

2. 'To the things themselves' is the English translation of the German zu den Sachen selbst. However, 'things' could also be translated back into German as Dinge, which in German has a 
more objective connotation than Sache. Sache carries some of the connotation of 'a case' - as in 'what is the case here?' - which includes more of the subjective aspect. A case does not seem to exist without someone experiencing it, whereas a thing does.

3. This does not mean that scientific knowledge is seen as 'merely subjective'. As Gordon (2006) maintains, phenomenology is compatible with scientific realism (at least a certain form of it).

4. As Ströker (1987, p. 132ff) points out, it is somewhat of a paradox that the lifeworld is both presupposed by science and informed by it. To resolve this paradox, a historical dimension has to be introduced; not, however, the ordinary history of external events, but what Husserl called the 'inner history' of science in terms of acts of meaning constitution. The reader is referred to Ströker's work for an interesting and more thorough analysis of Husserl's concept of the lifeworld and its significance for natural science.

5. Whereas phenomenology is focusing on investigating phenomena in the world, the object of research in phenomenography is the variation in the ways certain phenomena are experienced or handled by people of interest (Marton, 1981; Marton \& Booth, 1997). According to Marton and Booth (1997) phenomenography is a branch on the tree of phenomenology. As categorisation of ways of understanding is an essential part of the phenomenographic approach (see for instance Ebenezer \& Fraser, 2001; Ingerman \& Booth, 2003), the relevance of establishing such categories is not discussed from the viewpoint of the students' learning process, but from the point of view of science itself. The great variety of students' concepts and experiences are reduced in order to fit into categories, which are mutually exclusive and hierarchically ordered, going from the incomplete to the most complete and correct answer. Thus, students' experiences are not treated (strictly) phenomenologically, but as mere illustrations of analytically established categories of (mis)conceptions.

6. This is somewhat analogous to the reversing back of the 'ontological reversal' described above.

7. Peirce's semiotic triad has been the subject of much discussion within philosophy, linguistics and cognitive psychology; see, for instance, Eco (2000) and Ketner (1995).

8. See also below on Wagenschein's genetic method of instruction. The common factor is the focus on the bringing forth of understanding, but how this occurs is described in somewhat different terms by Wagenschein.

9. The authors mention Michael Faraday as being acutely aware of this problem. About Faraday as a phenomenologist avant la lettre, see below.

10. This 'history of science' approach to science education has a certain parallel with the phenomenographic approach described above (note 5), but instead of using the variation of conceptions among the students as material for instruction, one uses the variation of conceptions that have emerged in history.

11. The possibility of 'letting nature herself speak', that is, of a 'virgin' perception, untouched by culture, history and language, is nowadays considered obsolete. Most of the inheritors of Husserl's philosophy (Heidegger, Gadamer, Merleau-Ponty) denied this possibility, seeing all perception as necessarily enmeshed in language and determined by the horizon of the lifeworld (cf Gadamer, 1976). Nevertheless, there is a value in not abolishing the notion of 'nature's own voice', in order not to let our capacities for careful observation, intense listening to and dwelling in the phenomena dwindle.

12. Other German studies discussing or taking a point of departure in Wagenschein's science education are Dahlmann (1997), Jung (1997), Redeker (1995) and Rehm (2006).

13. Connected to the first edition of Goethe's complete works, Kürchners Gestamtausgabe, in the 1880 s and 1890 s, Steiner did the editing and commenting on Goethe's scientific writings (Steiner, 2000).

\section{Notes on contributors}

Edvin Østergaard is associate professor in Science Education at the Department of Mathematical Sciences and Technology, Norwegian University of Life Sciences, Norway. He currently also works as a composer. Bo Dahlin is professor in Education at the Faculty of Arts and Philosophy, Karlstad University, Sweden. His main interest is philosophy of education and the application of existential phenomenology to educational research and practice. Aksel Hugo is associate professor in Science Education at the Department of Mathematical Sciences and Technology, Norwegian University of 
Life Sciences, Norway. He has also worked as a Steiner Waldorf teacher and is currently head of an international Masters program in Steiner Waldorf education at the Rudolf Steiner University College in Oslo, Norway.

\section{References}

Alexandersson, M. (1994). Metod och medvetande [Method and consciousness]. Gothenburg, Sweden: Acta Universitatis Gothoburgensis.

Amrine, F., Zucker, F.J., \& Wheeler, H. (Eds.) (1987). Goethe and the sciences: A reappraisal. Dordrecht: Reidel.

Apple, M.W. (1990). Ideology and curriculum. New York \& London: Routledge.

Arons, A.B. (1982). Phenomenology and logical reasoning in introductory physics courses. American Journal of Physics, 50, 13-20.

Baird, J.R. (1999). A phenomenological exploration of teachers' views of science teaching. Teachers and Teaching: Theory and Practice, 5, 75-93.

Barnes, J. (2000). Participatory science as the basis for healing culture. In R. Steiner, Nature's open secret. Introductions to Goethe's scientific writings (J. Barnes, Trans., pp. 219-301). Great Barrington, MA: Anthroposophic Press.

Bateson, G. (1979). Mind and nature: A necessary unity. London: Fontana Paperbacks.

Bennett, J., Gräsel, C., Parchmann, I., \& Waddington, D. (2005). Context-based and conventional approaches to teaching chemistry: Comparing teachers' views. International Journal of Science Education, 27, 1521-1547.

Bevilacqua, F., \& Giannetto, E. (1995). Hermeneutics and science education: The role of history of science. Science \& Education, 4, 115-126.

Biggs, J. (1999). Teaching for quality learning at university. Buckingham, UK: Society for Research into Higher Education.

Blades, D.W. (2006). Levinas and an ethics for science education. Educational Philosophy and Theory, 38, 647-664.

Böhme, G., \& Shiemann, G. (Eds.) (1997). Phänomenologie der Natur [Phenomenology of nature]. Frankfurt-am-Main, Germany: Suhrkamp.

Bortoft, H. (1996). The wholeness of nature. Goethe's way towards a science of conscious participation in nature. New York: Lindisfarne Press.

Buck, P. (1986). Dämmerung. Über Verwandlungsdenken und Subtraktionsdenken [Dawning. On transformative thinking and subtractive thinking]. Neue Sammlung, 26, 518-524.

Buck, P. (1996). Phänomenologie!? [Phenomenology!?] Chimica Didactica, 22, 47-51.

Buck, P. (1997). Einwurzelung und verdichtung. Tema con variazione über zwei metaphern Wagenscheinscher didaktik ['Rooting in' and 'thickening'. Tema con variazione over two metaphors in Wagenschein's didaktik]. Dürnau, Germany: Kooperative Dürnau.

Buck, P., \& Mackensen, M.V. (1980). Ein interview über chemieunterricht an Waldorfschulen [An interview on teaching chemistry in Steiner Waldorf Schools]. Chimica Didactica, 6, 9-14.

Buck, P., \& Kranich, E.-M. (Eds.) (1995). Auf der Suche nach dem erlebbaren Zusammenhang. Übersehene Dimensionen der Natur und ihre Bedeutung für die Schule [Looking out for experiential connections. Neglected dimensions of nature and their significance for education]. Weinheim, Germany \& Basel, Switzerland: Beltz Verlag.

Carter, L. (2004). Thinking differently about cultural diversity: Using postcolonial theory to (re)read science education. Science Education, 88, 819-836.

Cobern, W.W., \& Aikenhead, G.S. (1998). Cultural aspects of learning science. In B. Fraser \& K.G. Tobin (Eds.), International handbook of science education (pp. 39-52). Dordrecht, The Netherlands: Kluwer Academic Publishers.

Dahlin, B. (2002). Den tunga vetenskapen. Lärarstuderandes uppfattningar av naturvetenskap med kontroversen mellan Goethes och Newtons optik som utgångspunkt [Heavy science. Teacher students' conceptions of science with the controversy between Goethe's and Newton's optics as frame of reference]. Karlstad, Sweden: Karlstad University Studies.

Dahlin, B. (2003). The ontological reversal: A figure of thought of importance for science education. Scandinavian Journal of Educational Research, 47, 77-88.

Dahlmann, W. (1997). Wie die fußspur eines vogels auf dem schnee. Zur vermeintlichen phänomenologie der atomaren welt bei Martin Wagenschein. Teil I: Die 'naturen', das phänomen und 
die wesenserkenntnis [Like the tracks of a bird in the snow. To the supposed phenomenology of the atomic world by Martin Wagenschein. Part I: The 'Natures', the phenomenon and the essence-knowing]. Chimica Didactica, 23, 84-93.

Donnelly, J.F. (1999). Schooling Heidegger: On being in teaching. Teaching and Teacher Education, $15,933-949$.

diSessa, A. (1993). Towards an epistemology of physics. Cognition and Instruction, 10, 105-225.

Eco, U. (2000). Kant and the platypus. Essays on language and cognition. London: Vintage.

Ebenezer, J.V., \& Fraser, D.M. (2001). First year chemical engineering students' conceptions of energy in solution processes: Phenomenographic categories for common knowledge construction. Science Education, 85, 509-535.

Faraday, M. (undated). The chemical history of a candle. A course of lectures delivered before a juvenile audience at The Royal Institution, London. London: Chatto \& Windus.

Faraday, M. (1990). An interview with M. Faraday from 1827. Retrieved August 27, 2007, from http://www.woodrow.org/teachers/chemistry/institutes/1992/Faraday.html

Flitner, A. (1990). Vorwort zur Neuausgabe. In M. Wagenschein (Ed.), Kinder auf dem wege zur physik [Introduction, in Children on their way towards physics] (pp. 3-8). Weinheim, Germany \& Basel, Switzerland: Beltz Verlag.

Freudenthal, H. (1993). Thoughts on teaching mechanics. Didactical phenomenology of the concept of force. Educational Studies in Mathematics, 25, 71-87.

Frykman, J., \& Gilje, N. (2003). Being there. In J. Frykman \& N. Gilje (Eds.), Being there. New perspectives on phenomenology and the analysis of culture (pp. 7-51). Lund, Sweden: Nordic Academic Press.

Gadamer, H.-G. (1976). The science of the life-world. In D.E. Linge (Ed.), Philosophical hermeneutics (pp. 182-197). Berkley/Los Angeles/London: University of California Press.

Gilbert, J.K. (2006). On the nature of 'context' in chemical education. International Journal of Science Education, 28(9), 957-976.

Goethe, J.W.V. (1960). Die metamorphose der pflanzen [The metamorphosis of plants]. Stuttgart, Fermany: Verlag Freies Geistesleben. (Original work published 1790).

GOETHE, J.W.V. (1971). Goethes farbenlehre [Goethe's theory of colours]. Ravensburg, Germany: Otto Maier Verlag. (Original work published 1810).

Goethe, J.W.V. (1988). Scientific studies. (D. Miller, Ed. \& Trans.). New York: Suhrkamp.

Gordon, P.E. (2006). Realism, science, and the deworlding of the world. In H.L. Dreyfus \& M.A. Wrathall (Eds.), A Companion to phenomenology and existentialism (pp. 425-444). Oxford: Blackwell.

Grebe-Ellis, J. (2005). Grundzüge einer phänomenologie der polarisation [Fundamentals of a phenomenology of polarization]. Phänomenologie der Naturwissenschaft, Band 3. Berlin: Logos Verlag.

Hamilton, J. (2000). Faraday. The life. London: Harper Collins.

Harvey, C.W. (1989). Husserl's phenomenology and the foundations of natural science. Athens, GA: Ohio University Press.

Heinemann, F. (1934). Goethe's phenomenological method. Philosophy, 9, 67-81.

Holdridge, C. (1996). A question of genes. Understanding life in context. Edinburgh, UK: Floris Books.

Hopmann, S. (2007). Restrained teaching: The common core of Didaktik. European Educational Research Journal, 6, 109-124.

Hugo, A. (2006). Når faget vokser ut av fenomenene. Naturen som historieforteller [Letting the subject grow out of the phenomena. Nature as storyteller]. IMT-Rapport, nr. 12/2006. Ass, Norway: Institute for Mathematical Sciences and Technology, Norwegian University of Life Sciences.

Husserl, E. (1931). Ideas: General introduction to pure phenomenology. New York: Humanities Press.

Husserl, E. (1970). The crisis of the European sciences and transcendental phenomenology. Evanston, IL: Northwestern UP.

Husserl, E. (1973). Cartesian meditations: An introduction to phenomenology. Dordrecht: Kluwer.

Ingerman, A., \& Booth, S. (2003). Expounding on physics: A phenomenographic study of physicists talking of their physics. International Journal of Science Education, 25, 1489-1508.

Jackson, M. (1996). Things as they are. New directions in phenomenological anthropology. Bloomington, IN: Indiana University Press. 
Jelinek, D., \& Sun, L.-L. (2003). Does Waldorf offer a viable form of science education? Sacramento, CA: CSU College of Education.

Jenkins, E.W., \& Nelson, N.W. (2005). Important but not for me: Students' attitudes towards secondary school science in England. Resarch in Science \& Technology Education, 23(1), 41-58.

Julius, F.H. (1984). Entwurf einer optik. Zur phänomenologie des lichts [An outline of optics. On the phenomenology of light]. Stuttgart, Germany: Verlag Freies Geistesleben.

Julius, F.H. (1988a). Grundlagen einer phänomenologischen chemie: Zum chemieunterricht der oberstufe [Foundations of a phenomenological chemistry. Teaching chemistry in the upper grades]. Stuttgart, Germany: Verlag Freies Geistesleben.

Julius, F.H. (1988b). Stoffeswelt und menschenbildung. Teil I: Chemie an einfachen phänomenen dargestellt [Substance and human education. Chemistry presented through simple phenomena]. Stuttgart, Germany: Verlag Freies Geistesleben.

Jung, W. (1997). Konstruktivismus, physikalismus und phänomenologie. In Erinnerung an Martin Wagenscheins hundertsten Geburtstag [Constructivism, physicalism and phenomenology. In memory of Martin Wagenschein's hundred-year birthday]. Zeitschrift für Didaktik der Naturwissenschaften, 3, 3-14.

Kaufmann, W. (1993). Discovering the mind. Volume 1. Goethe, Kant, and Hegel. New Brunswick \& London: Transaction Publishers.

Ketner, K.L. (Ed.) (1995). Peirce and contemporary thought. Philosophical inquiries. New York: Fordham University Press.

Knain, E. (2001). Ideologies in school science textbooks. International Journal of Science Education, 23, 319-329.

Kolisko, E. (1932). Über den ersten chemieunterricht [On the introductory teaching of chemistry]. Originally published as three articles in the journal Erziehungskunst, February 1932 (5th annual, no. 5), April/June 1932 (6th annual, no. 1-2), August 1932 (6th annual, no. 3).

Kozoll, R.H., \& Osborne, M.D. (2004). Finding meaning in science: Lifeworld, identity and self. Science Education, 88, 157-181.

Kranich, E.M. (2005a). Grundlinien einer phänomenologischen chemie [Foundations of a phenomenological chemistry]. In E.M. Kranich (Ed.), Chemie verstehen. Die bedeutung der elemente in substanz- und lebensprozessen (pp.15-46). Stuttgart, Germany: Verlag Freies Geistesleben.

Kranich, E.M. (Ed.) (2005b). Chemie verstehen. Die bedeutung der elemente in substanz- und lebensprozessen [Understanding chemistry. The significance of the elements in processes of substance and life]. Stuttgart, Germany: Verlag Freies Geistesleben.

Littledyke, M. (1996). Science education for environmental awareness in a postmodern world. Environmental Education Research, 2, 197-214.

Lukenchuk, A. (2006). Traversing the chiasms of lived experiences: Phenomenological illuminations for practitioner research. Educational Action Research, 14, 423-435.

Luft, S. (2005). Husserl's concept of the 'transcendental person': Another look at the HusserlHeidegger relationship. International Journal of Philosophical Studies, 13, 141-177.

Mackensen, M.V. (1981). Ein kapitel optikunterricht - das freie bild [A chapter of optics teaching the free image]. Elemente der Naturwissenschaft, 34, 1-7.

Mackensen, M.V. (1987). Stärke, eiweiß, zucker, fett. Einführende unterrichtsgebiete aus phänomenologischem ansatz für die chemieepochen der 7. und 8. klasse - mit versuchsbeschreibungen [Starch, protein, sugar, fat. Introductory fields of teaching out of phenomenological perspectives in chemistry for grade 7 and 8]. Kassel, Germany: Pädagogische Forschungsstelle beim Bund der Freien Waldorfschulen.

Marton, F. (1981). Phenomenography - describing conceptions of the world around us. Instructional Science, 10, 177-200.

Marton, F., \& Booth, S. (1997). Learning and awareness. Mahwah, NJ: Lawrence Erlbaum Associates.

Matthews, M.R. (Ed.) (1998). Constructivism in science education. Dordrecht, Boston, London: Kluwer Academic Publishers.

Mensch, J.R. (2001). Postfoundational phenomenology: Husserlian reflections on presence and embodiment. University Park, PA: Pennsylvania State University Press.

Merleau-Ponty, M. (1962). Phenomenology of perception (C. Smith, Trans.). London: Routledge \& Kegan Paul. 
Merleau-Ponty, M. (1968). The primacy of perception and other essays on phenomenological psychology, the philosophy of art, history and politics. Evanston, IL: Northwestern University Press.

Monk, R. (1991). Ludwig Wittgenstein: The duty of genius. London: Vintage.

Moran, D. (2000). Introduction to phenomenology. London \& New York: Routledge.

Østergaard, E. (2006). Naturfaglærerens doble blikk. In E. Knain \& E. Østergaard (Eds.), Artikkelsamling for PPU i fagdidaktikk [The science teacher's double focus] (pp. 39-54). Aas, Sweden: University of Life Sciences/Department of Mathematical Sciences and Technology Press.

Ott, R. (1960). Grundriß einer chemie nach phänomenologischer methode (Band 1) [Basic sketch for a chemistry according to phenomenological method (Volume I)]. Basel, Switzerland: R.G.Z. Linden.

Ott, R. (1962). Grundriß einer chemie nach phänomenologischer methode (Band 2) [Basic sketch for a chemistry according to phenomenological method (Volume 2)]. Basel, Switzerland: R.G.Z. Linden.

Redeker, B. (1995). Martin Wagenschein - Phänomenologisch gelesen [Martin Wagenschein - read phenomenologically]. Weinheim, Germany: Deutscher Studienverlag.

Rehm, M. (2006). Allgemeine naturwissenschaftliche bildung: Entwicklung eines vom begriff 'verstehen' ausgehenden kompetenzmodells [Bildung in natural science - the development of a model of competency based on the concept 'understanding']. Zeitschrift für Didaktik der Naturwissenschaften, 12, 23-44.

Resnick, L.B., Säljö, R., Pontocorvo, C., \& Burge, B. (1997). Discourse, tools, and reasoning. Essays on situated cognition. Berlin, Heidelberg, New York: Springer.

Roth, W.-M., \& Bowen, G.M. (1999). Complexities of graphical representations during ecology lectures: An analysis rooted in semiotics and hermeneutic phenomenology. Learning and Instruction, 9, 235-256.

Roth, W.-M., Bowen, G.M., \& Masciotra, D. (2002). From thing to sign and 'natural object': Toward a genetic phenomenology of graph interpretation. Science, Technology, and Human Values, 27, 327-356.

Roth, W.-M., McGinn, M.K., \& Bowen, G.M. (1998). How prepared are pre-service teachers to teach scientific inquiry? Levels of performance in scientific representation practices. Journal of Science Teacher Education, 9, 25-48.

Roth, W.-M., McRobbie, C.J., Lucas, K.B., \& Boutonné, S. (1997). The local production of order in traditional science laboratories: A phenomenological analysis. Learning and Instruction, 7, $107-136$.

Schieren, J. (1998). Anschauende urteilskraft: Methodische und philosophische grundlagen von Goethes naturwissenschaftlichem erkennen [Perceptual power of thinking: methodological and philosophical foundations of Goethe's scientific studies]. Düsseldorf/Bonn, Germany: Parerga.

Seamon, D., \& Zajonc, A. (Eds.) (1998). Goethe's way of science. A phenomenology of nature. New York: State University of New York Press.

Soentgen, J. (1997). Phänomenologische untersuchungen zum stoffbegriff [Phenomenological investigations of the concept of matter]. Chimica Didactica, 25, 197-221.

Spiegelberg, H. (1994). The phenomenological movement. A historical introduction (3rd revised and enlarged edition). Dxsordrecht/Boston/London: Kluwer Academic Publishers.

Steiner, R. (2000). Nature's open secret. Introductions to Goethe's scientific writings. (J. Barnes, Trans.). Great Barrington, MA: Anthroposophic Press.

Ströker, E. (1987). The Husserlian foundations of science. Washington: Center for Advanced Research in Phenomenology \& University Press of America.

Szybek, P. (2002). Science education: An event staged on two stages simultaneously. Science \& Education, 11, 525-555.

Van Manen, M. (1990). Researching lived experience. Human science for an action sensitive pedagogy. New York: State University of New York Press.

Wagenschein, M. (1968). Verstehen lernen [Learning understanding]. Weinheim, Germany: Beltz.

Wagenschein, M. (1983). Erinnerungen für morgen. Eine pädagogische autobiographie [Memories for tomorrow. A pedagogical autobiography]. Weinheim, Germany \& Basel, Switzerland: Beltz Verlag.

Wagenschein, M. (Ed.) (1990). Kinder auf dem wege zur physik [Children on their way towards physics]. Weinheim, Germany \& Basel, Switzerland: Beltz Verlag. 
Whitelegg, E., \& Parry, M. (1999). Real-life contexts for learning physics: Meanings, issues and practice. Physics Education, 34(2), 68-72.

Wolf, O. (1998). Grundlagen einer geisteswissenschaftlich erweiterten biochemie [Foundations of a spiritually extended biochemistry]. Stuttgart, Germany: Verlag Freies Geistesleben.

Wolpert, L. (1992). The unnatural nature of science. Cambridge, MA: Harvard University Press.

Zajonc, A. (1999). Catching the light. The entwined history of light and mind. New York \& Oxford: Oxford University Press. 